\title{
Legal Knowledge Management System on Family Law for Society
}

Nur Putri Hidayah ${ }^{1}$, Galih Wasis Wicaksono ${ }^{2}$

\author{
${ }^{1}$ Faculty of Law, Universitas Muhammadiyah Malang, Indonesia \\ nurputri@umm.ac.id \\ 2 Faculty of Engineering, Universitas Muhammadiyah Malang, Indonesia \\ galih.w.w@umm.ac.id
}

\begin{abstract}
Introduction to The Problem: Until 2018, the problem in the realm of family law (marriage and inheritance) were the highest problems faced in religious courts. Through the Community Program for Women and Children Care (Madupria), the family welfare movement of Sumbersekar Village (PKK Desa Sumbersekar) wants to help in speaking out about the family's legal problems that have been faced by the community in Sumbersekar village. Family legal issues in the community can be diminished if the community has good legal knowledge (intelligent legal). Nowadays, the current digital, legal collaboration, and information technology, should be utilized. One of the ways is through a legal knowledge management system, which will create a family legal savvy community in Sumbersekar village.

Purpose/Objective Study: The purpose of this research is to perceive why family law problems occur in the village of Sumbersekar, and what kind of family law knowledge is needed, as well as modeling cases through a legal knowledge management system.

Design/Methodology/Approach: This is multidisciplinary research that uses sociological legal research method, as well as using the method of research and development in the field of information technology.

Findings: Family law issues in these cases are the rights and obligations of husband and wife and the distribution of inheritance. The causes of legal problems that happened regarding the rights and obligations of husband and wife are economic problems $(10 \%)$, lack of education (20\% lack of knowledge), poor communication (25\%), and adverse environmental impacts (45\%). In comparison, the problem of inheritance is caused by internal personal desires on controlling legacy (40\%) and the lack of education/knowledge (60\%). Whereas, the required legal experience to overcome these issues are family law and inheritance law is consisting of statutory regulations, judges' decisions, and scientific articles.
\end{abstract}

Paper Type: Research Article

Keywords: Knowledge Management System; Society; Family Law

\section{Introduction}

Currently, disputes in the field of family law are very much happening in the community. It occurs since family law is very close to human private and social 
problems. The relationship of a person in the field of family law even begins in the womb until death. Family law, according to Mardani, is a law governing the family formation, rights and obligations between husband and wife, rights and obligations between parents and children, and vice versa, the split of marital relations, heredity, and inheritance (Mardani, 2017).

Commonly, family law issues are usually solved in court (Yunanto, 2019). Based on the report of the Religious Court of Malang district, from 2012 to 2016, the highest rate of cases is the marital dispute and inheritance dispute (Pengadilan Agama Malang, 2017). The numbers still encompass the same issues until 2018 (Pengadilan Agama Malang, 2018).

Table 1. Number of cases per year in the Religious Court of Malang and Kepanjen

\begin{tabular}{|c|c|c|c|}
\hline Years & Types of Case & $\begin{array}{c}\text { Religious Court of } \\
\text { Malang }\end{array}$ & $\begin{array}{c}\text { Religious Court of } \\
\text { Kepanjen }\end{array}$ \\
\hline \multirow[t]{3}{*}{2018} & Marriage & 1573 & No Data \\
\hline & Inheritance & 22 & No Data \\
\hline & Sharia Economics & 3 & No Data \\
\hline \multirow[t]{3}{*}{2017} & Marriage & 2520 & No Data \\
\hline & Inheritance & 99 & No Data \\
\hline & Sharia Economics & 2 & No Data \\
\hline \multirow[t]{3}{*}{2016} & Marriage & 2656 & 7975 \\
\hline & Inheritance & 52 & 31 \\
\hline & Grant & 1 & 0 \\
\hline \multirow[t]{3}{*}{2015} & Marriage & 2587 & No Data \\
\hline & Inheritance & 35 & No Data \\
\hline & Sharia Economics & 2 & No Data \\
\hline \multirow[t]{3}{*}{2014} & Marriage & 2695 & 8315 \\
\hline & Inheritance & 27 & 32 \\
\hline & Grant & 2 & 0 \\
\hline \multirow[t]{3}{*}{2013} & Marriage & 2493 & 7731 \\
\hline & Inheritance & 41 & 25 \\
\hline & Grant & 0 & 1 \\
\hline
\end{tabular}

Table 1 shows that the family legal problems, both marital issues and inheritance, have become the most consulted topic in Sumbersekar Village. The community usually consults the matters through The Community's Care for Women and Children (i.e., Masyarakat Peduli Perempuan dan Anak, abbreviated as Madupria) (Hidayah \& Komariah, 2019). Madupria is the Sumbersekar Village program carried out by the Empowerment System of Family Welfare (i.e., Pemberdayaan Kesjahteraan Keluarga, abbreviated as PKK) of Sumbersekar Village since 2012.

The consultation of family problems in Madupria is a form of legal protection as found in article 28 of The 1945 Constitution, Act No. 1 of 1974 on Marriage, and Regulation of Minister of Home Affairs of the Republic of Indonesia No. 1 of 2013 on Community Empowerment through Family Movement and Family Welfare. In article 28 of The 


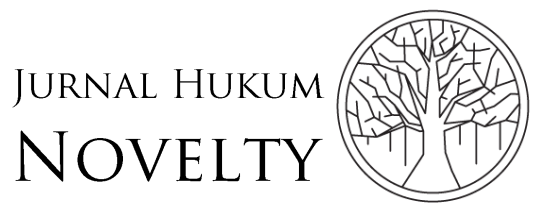

Volume 11, Issue 01, 2020, pp. 68-85

1945 Constitution, it comprises the fulfillment of citizen rights to form a family, protection of the law, equality of law, and justice (Krisnawaty et al., 2010). Meanwhile, The Regulation of The Minister of Home Affairs No. 1 of 2013 regulates on the community empowerment through the presence of empowerment movement and family welfare. Its function is to realize the prosperity towards the realization of the family's faith, which devoted to God Almighty, nobility and virtuous cycle, health and prosperous life, development and independence, gender equality, legal justice, and social awareness.

Problems in the field of family law can be minimized if the community has good legal knowledge (Purba, 2017). The condition to understand the law is not something exaggerated, considering that the code is the media of social interaction organizer (Mawardi, 2015) that can prevent human behavior from nature contrary to the rule of law (Diab, 2014). In doing so, there must be attempts to providing the community with legal education (Goodwin \& Maru, 2017).

For practical and massive education attempts, the advance of the information systems support is necessary (Joko, 2010). The form of information systems in legal matters is known as a legal knowledge management system. From a technological perspective, knowledge management is a concept where information is transformed into knowledge and makes it easier for people to implement it (Pujadi \& Tumar, 2016).

Previous research showed that legal knowledge could minimize the occurrence of law issues (Purba, 2017). In the field of Islamic Law, the legal knowledge management system can be used to gather information and to maintain knowledge of Islamic culture diversity (Afrianty \& Marzuki, 2015). It is also possible to gather legal documents to support the work of law firms, law scholars, and in-house legal offices in financial institutions, as well as public sector organizations (Boella et al., 2016).

However, until now, there has been no knowledge management system compiled to gather legal knowledge regarding family law. Whereas, as data gave above, marriage and inheritance that is part of the family law are the most prominent cases handled by judges in the Religious Court of Malang Kepanjen district.

This research aims to excavate why family law problems can occur in Sumbersekar Village. The cause will be a reference to what kind of family law knowledge is needed, as well as modeling knowledge into a legal knowledge management system. Following the scope of knowledge in family law that will be included in the system, the topic of marriage and inheritance is chosen as the most common family law problem faced in Religious Court in Malang and Kepanjen. Additionally, a knowledge management system can be created in the form of websites and Android applications that serve as a repository of legal knowledge that can be obtained from various sources. 
Figure 1. Legal knowledge management system scheme

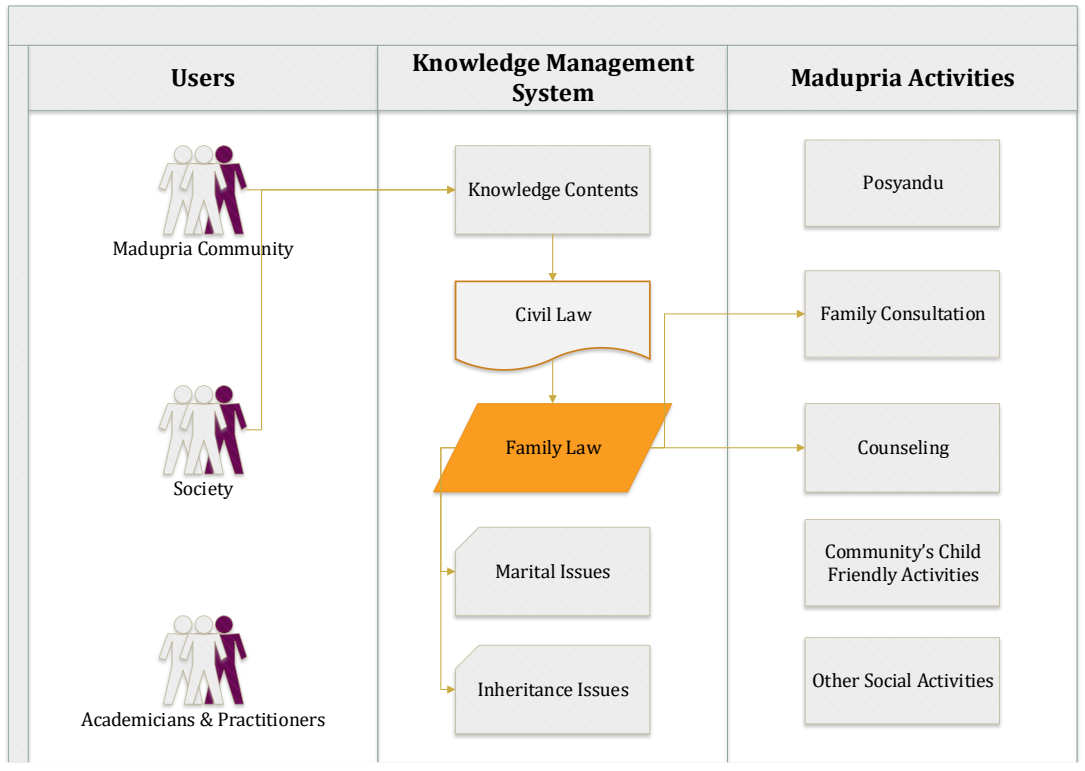

The legal knowledge management system is built based on various activities that have been implemented since 2012. It includes family consultation activities and an extension of routine operations. Suitable technology in the form of a legal knowledge management system website designed and developed in this research is expected to be a means of technology transference (advancement on soft skills development) of Madupria members, and the transference of legal knowledge through the system.

The formulation of problems that will be resolved in this study are: (1) Why do family law problems often occur in Sumbersekar village; (2) What legal knowledge is needed to solve the causes of family law problem that is regularly consulted on Madupria consulting activities; and (3) How to model the knowledge and build up the management system to support the implementation of consulting activities and counseling program of Madupria.

Time constraints and the ability of researchers in this study led to several things that limit the scope of this research. The first one is the field of research that will be conducted on family law, which covers marital and inheritance matters. The second is the source of knowledge adapted to the legal knowledge management system that encompasses a set of legislations, articles, and judgments.

The model development used implements the Case-Based Reasoning method (CBR). In legal studies, the use of case-based reasoning is particularly relevant to the excavation of knowledge in a set of court decisions. The development of the rulebased reasoning model and method can be done by implementing an expert system with extracting the knowledge from laws and regulations. Meanwhile, the 


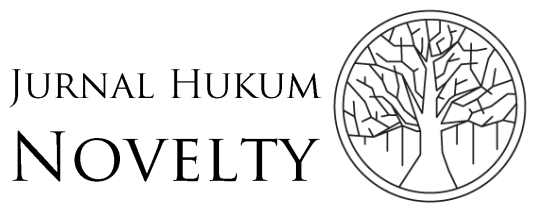

Volume 11, Issue 01, 2020, pp. 68-85

development of text mining can be done in articles and court decisions that are extracted using various methods in natural language processing.

\section{Methodology}

This research is multidisciplinary research combining sociological legal research methods in the field of law (Sonata, 2014) with research and development methods used in the field of informatics. Interdisciplinary research is a combination of several different disciplines to see a phenomenon or the same object (Wiratraman, 2019). Sociological law research is used to answer the formulation of the problem about the causes of family law problems at the research location, such as the method used in a study that aims to find the cause of a motorcycle theft crime (Marghobi, 2014). Moreover, by using this method, it is possible to conduct multidisciplinary research because it views the law from the perspective of empirical nature among the people (Sonata, 2014). The results of the study were elaborated using the knowledge management life cycle (KMLC) method (Surianti, Banyal, \& Wahab, 2017).

Figure 2. Methods of sociological legal research and knowledge management life cycle

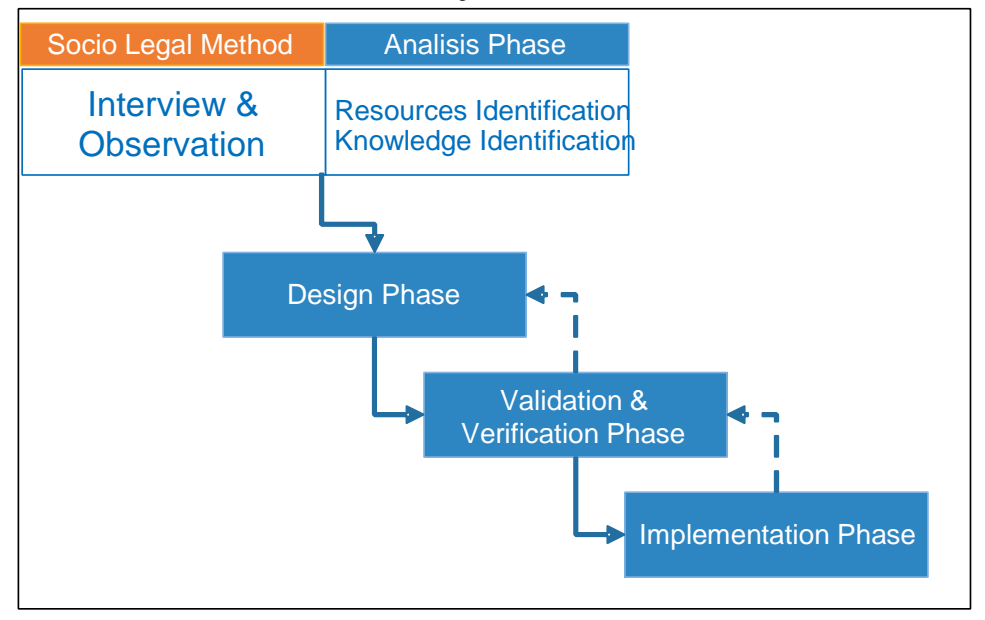

The first stage in this research was taken by conducting sociology and legal analysis to know the cause of family law problems that are often consulted by the public on Madupria Consulting Activities. Additionally, this research aims to understand what legal knowledge is needed to solve a family law problem that is often consulted on Madupria consulting activities. The first and second objectives can be achieved by collecting primary data. The primary data obtained by conducting the questionnaire to the Sumbersekar Village community, who also a cadre of PKK in this village. The survey was done through the sampling method without questioning the community as a whole. Purposive sampling is used as the sample determination method in this study (Soekanto, 2006). From 85 questionnaires, only 24 people were willing to answer. The data collected from surveys were processed in such a way, so the second objective is obtained, which will invest any legal knowledge needed to be implanted into the legal knowledge management system. 
In the second stage, the system design analysis was conducted based on the results of knowledge analysis at the first stage. The next step was validating and verifying the knowledge and systems, which then would be implemented in the order as the last step.

\section{Results and Discussion}

\section{Causes of family law problems in Sumbersekar village}

Based on the conducted research, the variety of marital problems that often occur in Sumbersekar village are as follows:

Chart 1. Types of Marital Issues in Sumbersekar Village

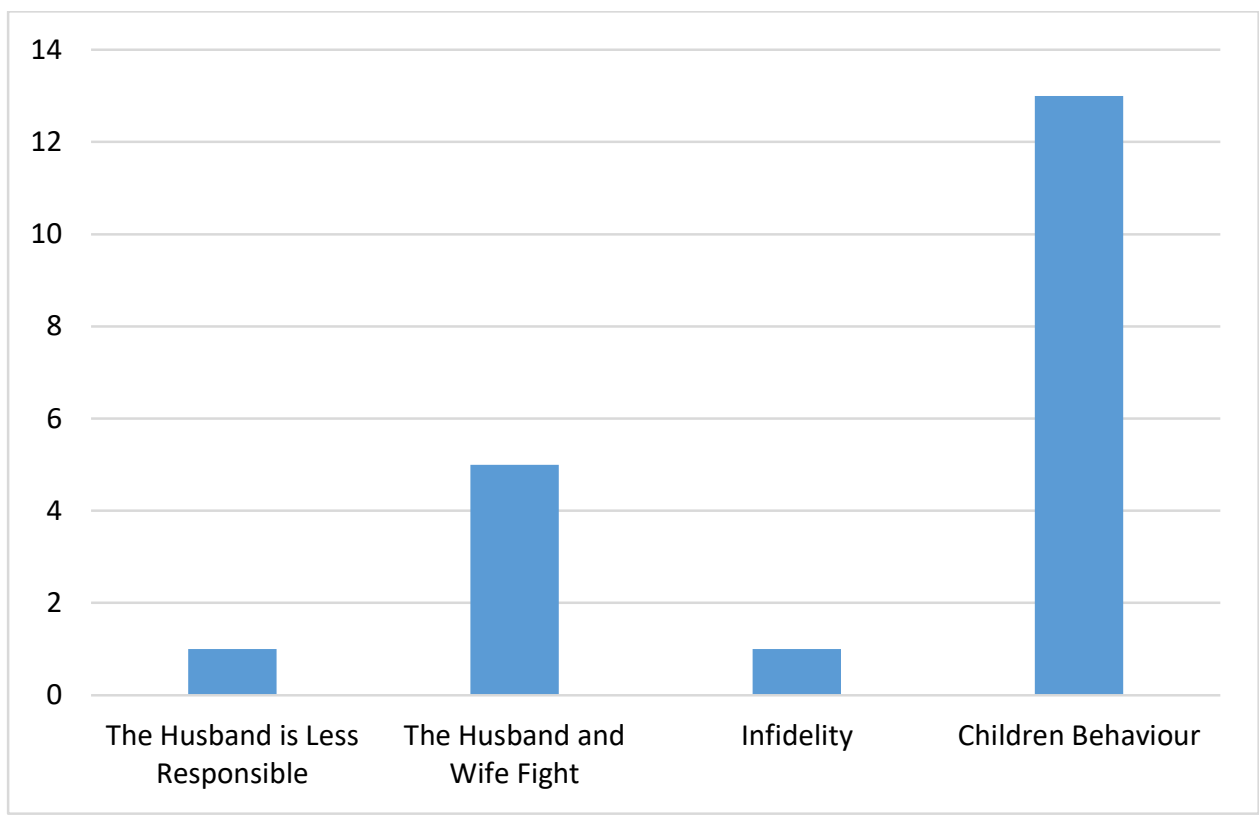

It can be seen from Chart 1, the husband's lack of responsibility and infidelity both are $5 \%$ of marital cases in the village. This percentage shows the least numbers compared to other matters. The highest rate is the negative children's behaviors, such as delinquency, less obedience towards parents, etc. Moreover, the remaining 25\% is caused by the fight that happens between husband and wife. All of these cases are caused by several things shown in Chart 2 . The lowest number of these causes is $10 \%$, which is economic problems. Meanwhile, the top caused-problem is the bad influence caused by the community in their environment, which as high as $45 \%$. Other issues faced in Sumbersekar Village are caused by the lack of education, which hits the number of $20 \%$ and bad communication in the family by $25 \%$. 
Chart 2. The Causes of Marital Problems in Sumbersekar Village

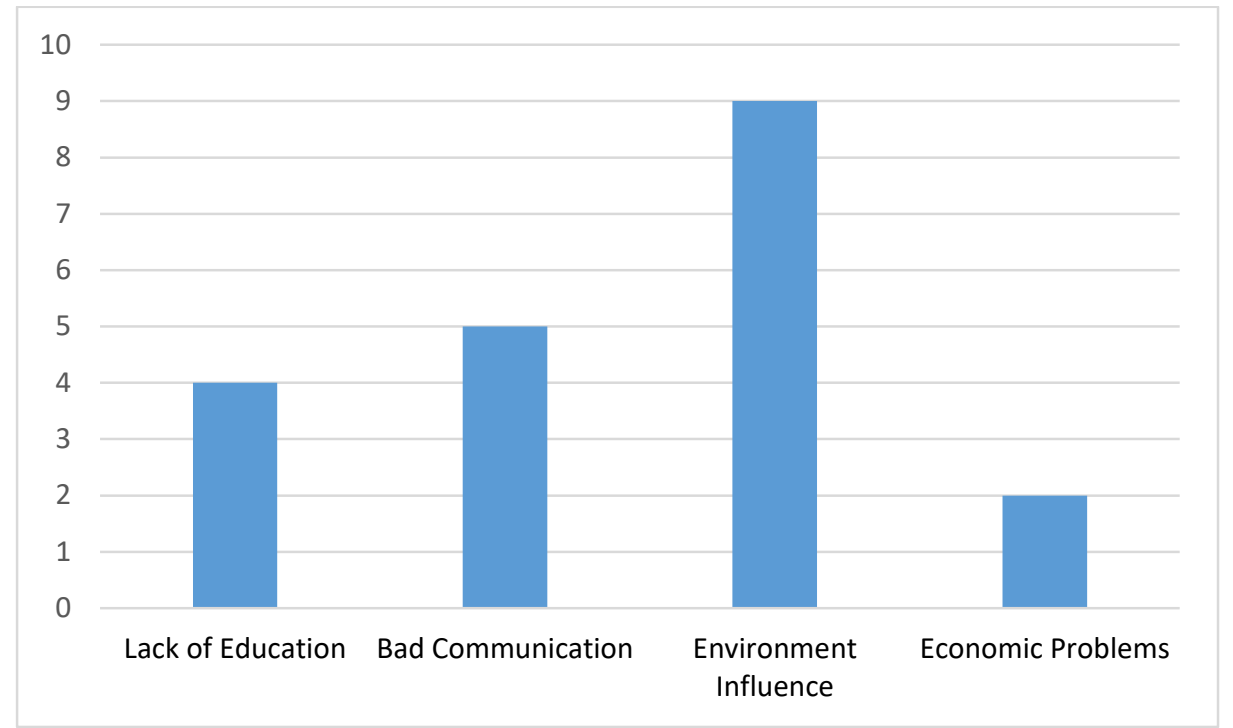

Following the marital issues is inheritance cases, which divided into two problems, which are the problem of the adopted children and the dispute between the heirs. Chart 3 elucidates that $60 \%$ of the issues are based on the existence of adopted children. It is the claim from those who feel that they have the inheritance rights. Meanwhile, the other $40 \%$ is the common quarrel that happens between the heirs on a shared-inheritance. These two problems are caused by, as it is shown in Chart 4, the lack of education and self-interest. The lack of knowledge is at the peak of $60 \%$, and selfishness hits the number of $40 \%$.

Chart 3. Inheritance issues in Sumbersekar village

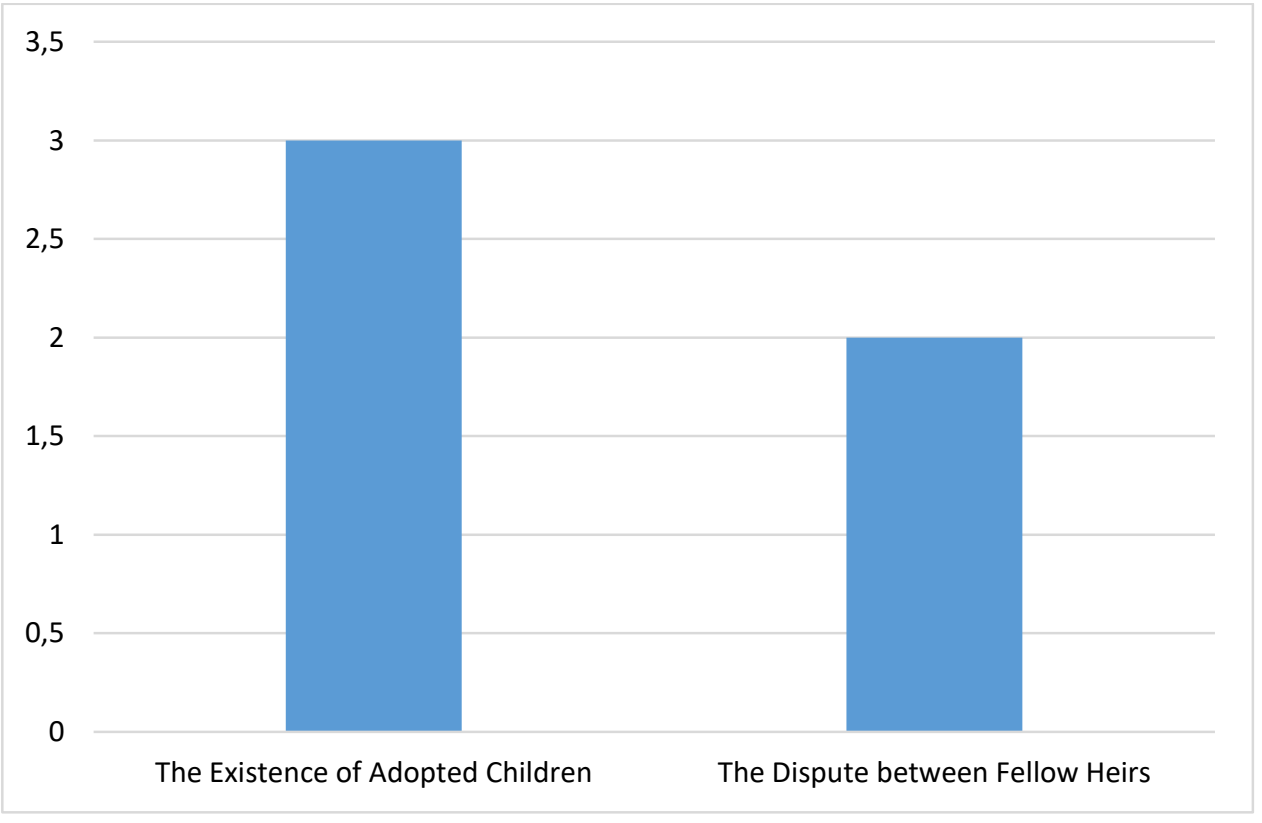


Chart 4. The cause of inheritance problems in Sumbersekar village

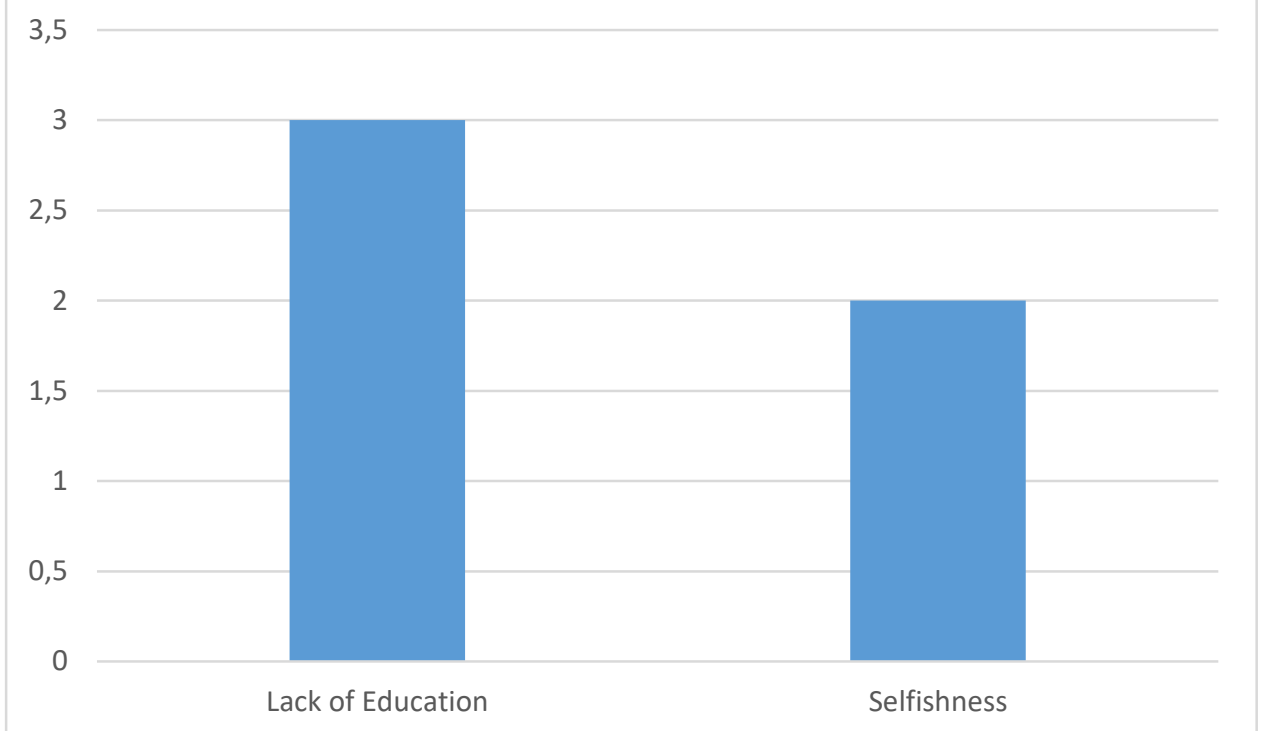

The self-internal cause is that both adopted children and heirs understand their shares. But, because of their self-interest to take control of the inheritance, there are conflicts over the struggle of proprietorship. Most of the community in Sumbersekar Village is, in fact, unaware of the inheritance law. It then leads to the ego on the idea of willing to do anything to hold the proprietorship above any other rights.

Legal knowledge needed to solve the legal problems of Sumbersekar village family

Referring to the previous discussion, if it is labeled, then the issue of family law could be seen as follows:

Table 2. The list of family law problems and their reasons

\begin{tabular}{clll}
\hline No & \multicolumn{1}{c}{ Problems } & \multicolumn{2}{c}{ Causes } \\
\hline 1 & The husband's lack of responsibility & 1.1 & Lack of Education \\
\cline { 3 - 4 } & & 1.2 & Bad Communication \\
\hline 2 & The husband and wife altercation & 2.1 & Bad Communication \\
\hline 3 & Infidelity & 3.1 & Bad Communication \\
\hline 4 & Children behavior & 4.1 & Economic Problems \\
\cline { 3 - 4 } & & 4.2 & Environment Influence \\
\cline { 3 - 4 } & & 4.3 & Lack of Education \\
\hline 5 & The existence of adopted children & 5.1 & Lack of Education \\
\hline & & 5.2 & Selfishness \\
\hline 6 & Conflicts happen between the heirs & 6.1 & Lack of Education \\
\hline
\end{tabular}




\subsection{Selfishness}

Based on inventory problems and causes mentioned in Table 2, the cultivation of legal knowledge management system is needed. Hence, legal knowledge needs to be implanted from various legitimate sources such as rules, judges' decisions, and journal articles. Under the family law problems that are currently faced by the community of Sumbersekar village, other family law knowledge as a reference source for those in resolving the legal issues among the families is necessary.

The legislation is used as a reference because it is a source of formal law in Indonesia (Ngutra, 2016). Additionally, if there will be any dispute, then both disputes (marital and inheritance issues) will be resolved in the authority of the Supreme Court as well as the Constitutional Court as the legal reference by the law (Al-Fatih, 2018). The judge's judgment is made as reference material to be a concrete example of disputes happening in the community within family legal issues. While the article is used as a reference material due to the validity of existing data in journal articles.

\section{Knowledge Management System to Support the Implementation of Program for Madupria in family Welfare Movement in Sumbersekar Village}

Information systems, as part of information technology, can be known as a knowledge management system (Al-Rizki, Wicaksono, \& Azhar, 2017). From a technological perspective, knowledge management is a concept where information is transformed into further action to simplify people's access to it. As the details, the legal knowledge represented in the form of Knowledge Management System can be created on web and mobile platforms that serve as repository models distribution of legal knowledge to the community. The platforms to be named as Maduhukum (i.e., Masyarakat Peduli Hukum). The legal knowledge that is provided can be obtained from various sources.

Figure 3. Legal knowledge sources in Maduhukum Knowledge Management System

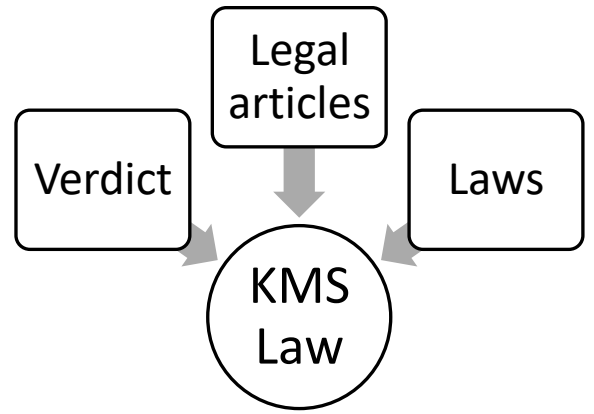

Application Maduhukum provides a knowledge management system in the field of law. As we know that legal matters are vast and varied, such as in the area of private law, which includes civil law, Islamic law, customary law, and so forth. Moreover, public law also contains several sub-fields such as criminal law, constitutional law, state administrative law, and so on. Besides, there is still convergence, such as trade law, labor law, agrarian law, etc. 
Given the broadness field of the law, the application of Maduhukum provides facilities needed in the form of a knowledge development model of legal branches that can be added gradually. It indicates that with the technology applied on Maduhukum, the organizer can add some legal groups by adding the type of law, followed by adding the judicial branches. This function makes Maduhukum a very dynamic and flexible mobile application based on the changing needs of the users, which is the community.

Figure 4. Illustration of legal knowledge sources group in Maduhukum

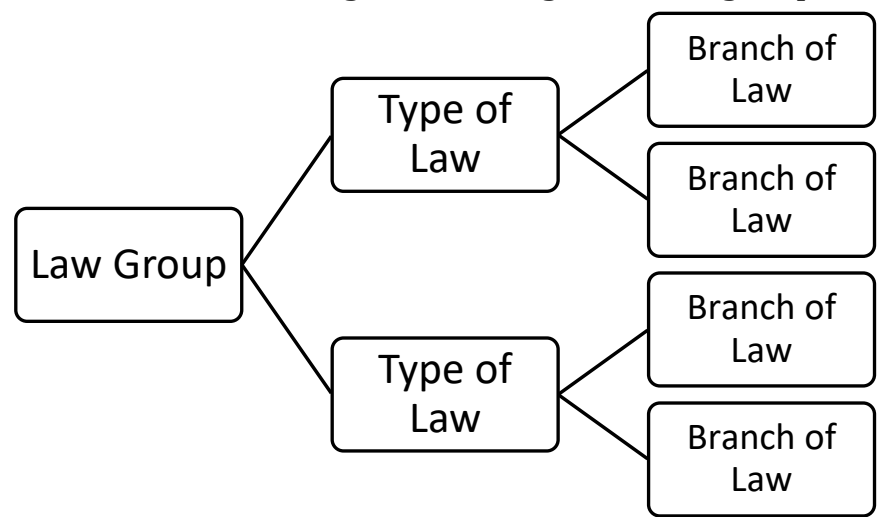

Until now, legal knowledge has been augmented in the Maduhukum mobile application that covers private law groups within the type of Islamic law. The legal branches available are the inheritance law, the marriage law, and the law of waqf. Maduhukum mobile application is being tested to the linked case study model faced by the community in Sumbersekar Village, Malang.

The process of developing the Maduhukum mobile app begins with the process of analysis of needs based on interviews conducted by the team of developers with the citizens, the village instruments, practitioners, and academicians. Through the study of the meetings, it has successfully formulated the functional needs of each user as described below:

Table 3. Practical needs of the application of Maduhukum

\begin{tabular}{llll}
\hline No & Users & Requirement & Description \\
\hline 1 & People & 1. Legal consultation & Community members \\
& & 2. Examples of legal dispute & \\
& & resolution/legal knowledge & \\
& & 3. Inheritance Simulation & \\
& & 4. Legal Counseling & Information \\
& & 1. Managing the community & Community Admins \\
& Manager & 2. Monitoring legal & \\
& & consultation & \\
& 3. Legal knowledge & \\
& 4. Managing legal counseling &
\end{tabular}




\begin{tabular}{|c|c|c|c|}
\hline No & Users & Requirement & Description \\
\hline 3. & $\begin{array}{l}\text { Legal } \\
\text { experts }\end{array}$ & $\begin{array}{l}\text { 1. Interacting in a legal } \\
\text { consultation with the } \\
\text { community }\end{array}$ & $\begin{array}{l}\text { Internal and external } \\
\text { experts }\end{array}$ \\
\hline 4. & Academics & 1. Managing legal knowledge & $\begin{array}{l}\text { 1. Laws and regulations } \\
\text { 2. Judges' court verdict } \\
\text { about marriage and } \\
\text { inheritance. } \\
\text { 3. Journal Articles that } \\
\text { speak about marriage } \\
\text { and inheritance. }\end{array}$ \\
\hline
\end{tabular}

Through the app, the community managers can add several topics of legal discussion matters on Maduhukum mobile application. Additionally, community managers could also be able to adjust the needs of the community.

Figure 5. Sample of the extracted lawsuit in the Maduhukum app as part of legal knowledge

\begin{tabular}{|c|c|c|c|c|c|c|c|c|}
\hline $\begin{array}{l}\text { Nomor } \\
\text { Perkara }\end{array}$ & Perihal & Lokasi $\uparrow \downarrow$ & Obyek Sengketa & $\begin{array}{l}\text { Cabang } \\
\text { Hukum }\end{array}$ & Status & Aksi & & \\
\hline 0005/Pdt.G & \multirow{6}{*}{ Gugat Waris } & Tergugat: & Sebidang Tanah Pekarangan dengan Luas Tanah $171 \mathrm{~m}^{2}$ (Seratus & Hukum & Aktif & 㕩 & $\sqrt{6}$ & fif \\
\hline \multirow[t]{5}{*}{ /2018/PA.Kab.Mn. } & & Madiun Kab. & Tujuh Puluh Satu Meter Persegi ) yang di atasnya telah didirikan & Waris & & & & \\
\hline & & Penggugat: & sebuah bangunan di Desa Slambur Kecamatan Geger Kabupaten & & & & & \\
\hline & & Madiun Kab. & Madiun Propinsi Jawa Timur dengan Sertifikat Hak Milik Nomor : & & & & & \\
\hline & & Pengadilan: & 434 yang di keluarkan oleh Kantor Pertanahan Kabupaten Madiun & & & & & \\
\hline & & Madiun Kab. & tertanggal 17 juni 2005 & & & & & \\
\hline
\end{tabular}

Legal knowledge derived from the extraction of a court ruling on Maduhukum is represented in the form of text documents which are classified into several pieces of information namely:

1. The article number, which contains a no-court identity.

2. The legal subject, which contains a summary of matters.

3. The location, which contains the information of the defendant domicile or plaintiff.

4. Dispute object, which includes details of dispute object in the matter.

5. The subject matter.

6. Petitum, which contains the information on the lawsuit filed by the plaintiff.

7. The verdict, which includes the ruling information established by the court judge.

8. The year of matter. 
Figure 6. Summary of legal knowledge for Community communities

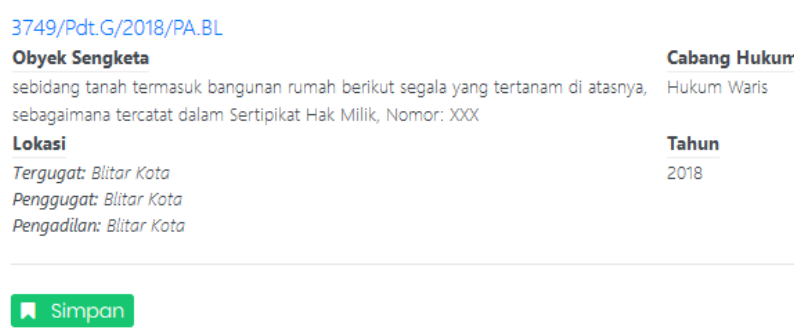

Maduhukum mobile application also implements Information Retrieval Technology (reissue information) on consulting the system with experts. When the community asks questions, the system will automatically detect the similarity to the problems that ever previously faced by the public with a court ruling and a scientific article relevant to the problem that is stored in the legal knowledge database.

Figure 7.2 The flow of knowledge similarity measurement

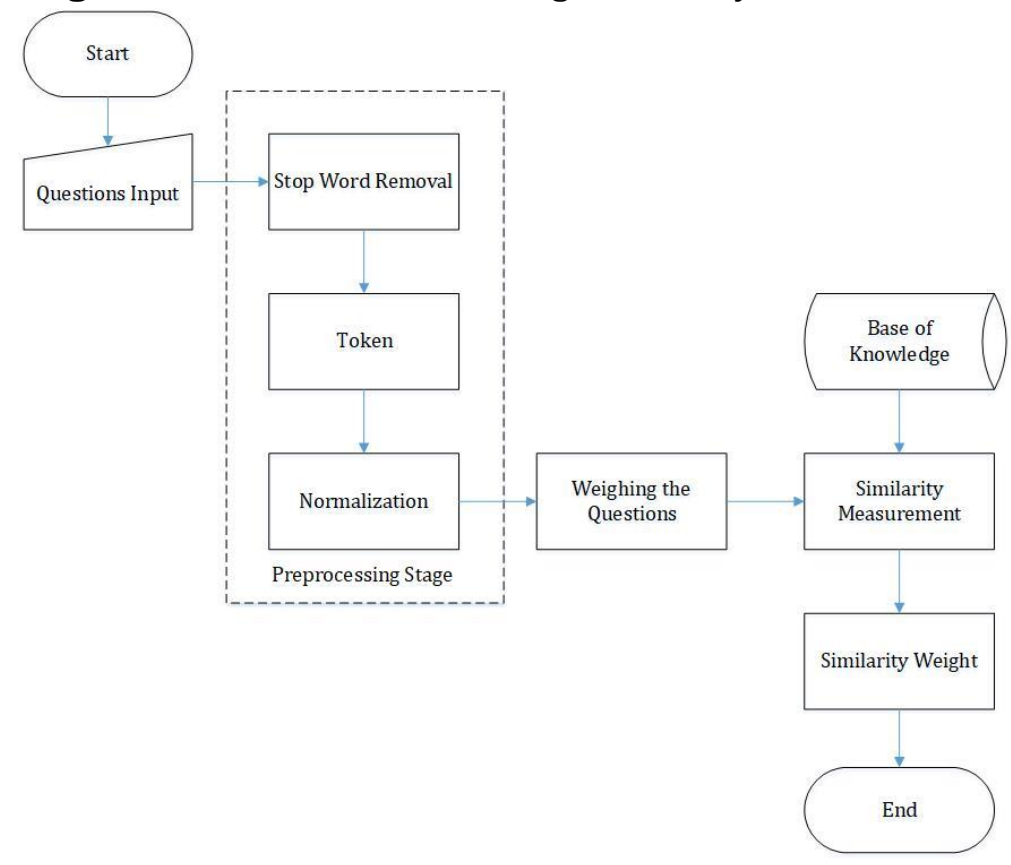

The result of information retrieval on Maduhukum mobile application can be seen in the legal consultation feature, as shown in Figure 6 and Figure 7, in which Maduhukum is capable of detecting the similar questions using the legal knowledge relevancy and based on the level of resemblance. This feature is expected to be able to provide a realistic idea within the legal cases faced by the community members. 
Figure 8. Questions feature in the legal consultation

\begin{tabular}{|c|c|c|c|c|c|c|c|c|c|c|c|c|c|c|}
\hline \multirow[t]{2}{*}{ Pertanyaan } & B & $I$ & $\underline{\mathbf{U}}$ & $\theta$ & s & $\mathbf{X}^{2}$ & $\mathbf{X}$ & 16. & $\mathbf{A}$ & r & $\equiv$ & $i \equiv$ & $\equiv$ & $\mathbf{T} t^{*}$ \\
\hline & \multicolumn{14}{|c|}{ bagaiamana pembagian waris antara ibu dan anak jika suami meninggal? } \\
\hline
\end{tabular}

Figure 9. Results of knowledge similarity measurement by questions

\section{Pengetahuan Putusan Pengadilan}

Klik untuk memilih

Nomor Perkara: 4434/pdt.g/2018/pa kab mlg

Kemiripan: $20 \%$

Nomor Perkara: 6366/pdt.G/2018/PA kab mlg

Kemiripan: 20\%

Nomor Perkara: 4434/pdt.g/2018/pa kab mlg

Kemiripan: $20 \%$

Community management is one of the most essential and serviceable features for community members who want to join a community. The application itself is formed and proposed by the community members; then, the proposal will be processed by the administrator.

Figure 10. Community Registration flow in application Maduhukum

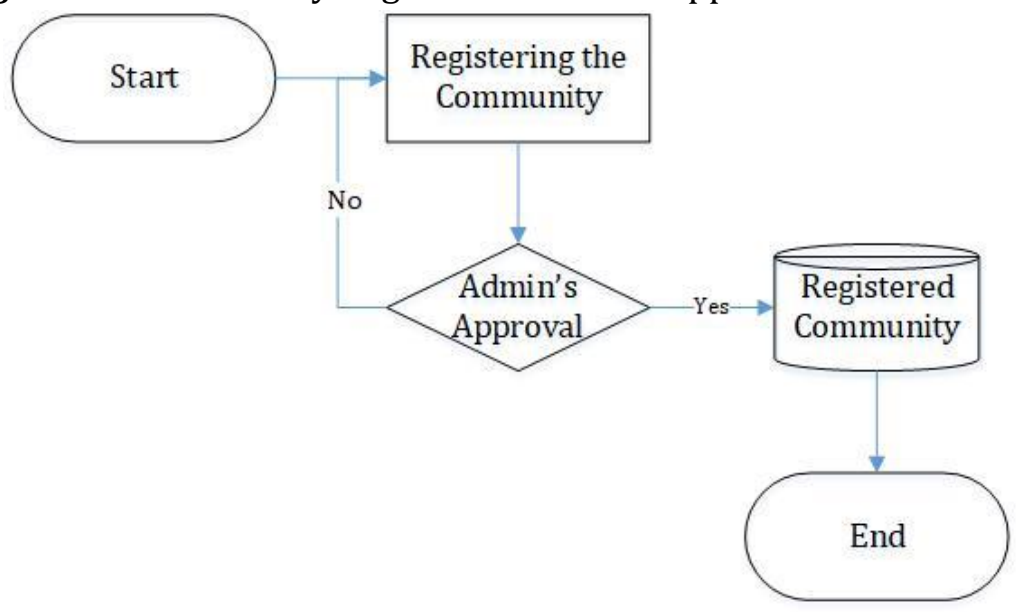

Every community that wants to join the Maduhukum app should complete various data and supporting documents to proving the community's legality. Figure 10 shows 
a 'yes' and 'no' decision regarding the data completion of the community. Besides, the administrator will also be screening the proposed organizations/communities, either by searching for related information on the internet or contacting the relevant parties. This act is being conducted as a manifestation towards possible misapplication on the usage of Maduhukum mobile application linked to any concern or improper activities.

Another provided feature and is a significant one is a legal consultation. The feature provides both question and answer, which can be accessed by the internal experts (community members designated as experts) and the external experts (experts provided by the app). It also offers an Islamic inheritance calculation simulator to support the user's needs by various problems faced by the Islamic inheritance system in family law. Legal consultation procedures, as shown in Figure 11, are initiated by community members who ask questions (Penanya). Based on Figure 12, after the proposed issue, then, the community members can attach supporting documents or files needed, as well as adding some legal knowledge as a description to the relevance of legal issues faced with the current legal understanding.

Figure 11. Legal Consultation

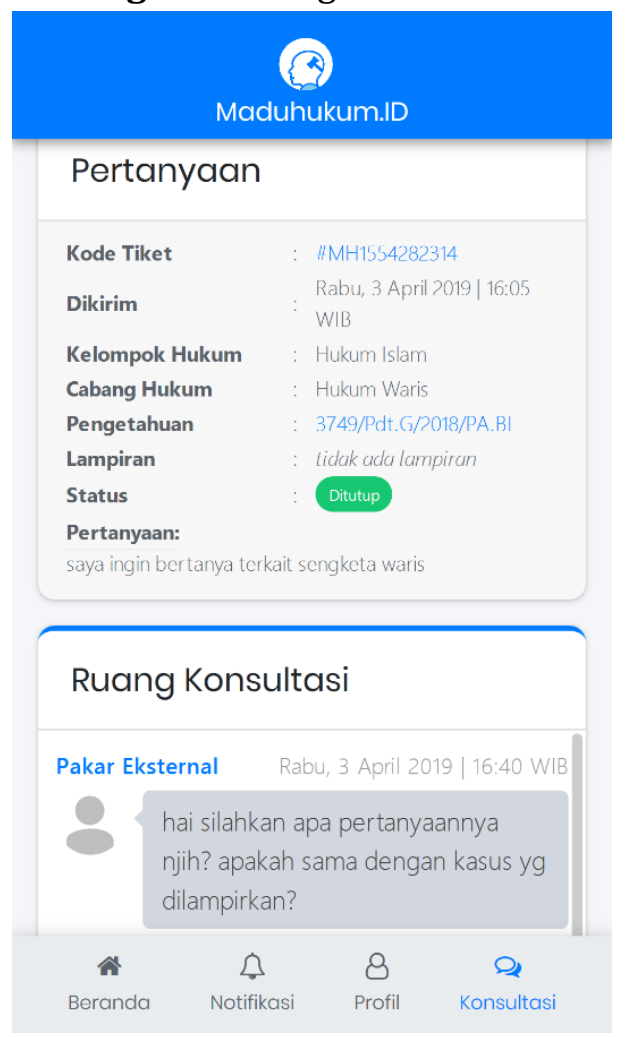

Figure 12. Consulting Attachments

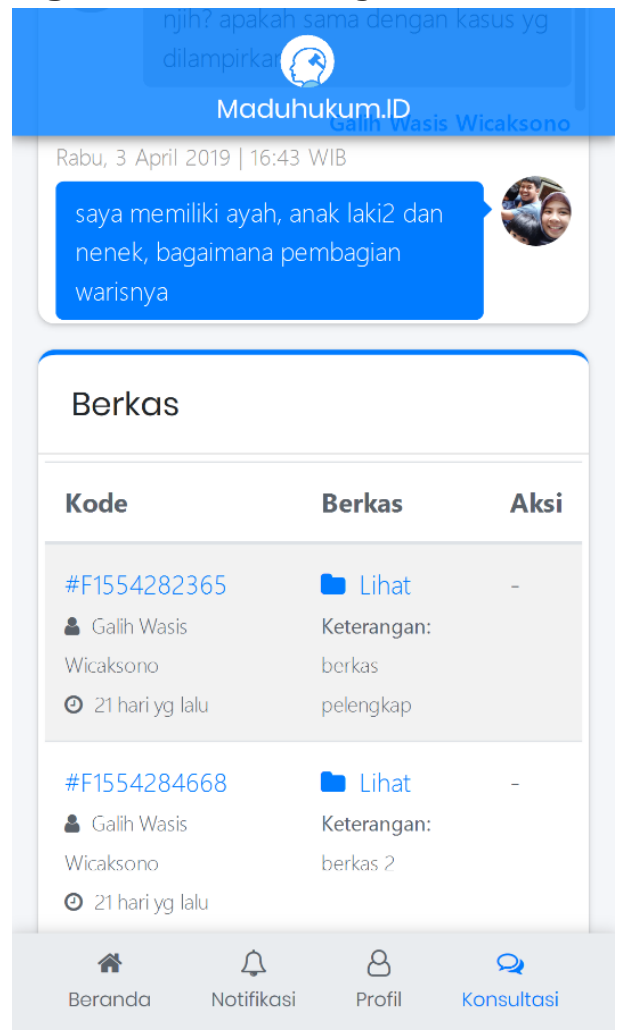

Subsequent notifications will be submitted to the internal experts and external experts, internal experts will answer questions, and the answers can be attached to a file/document supporting those answers. In case the internal expert does not respond, external experts can answer the question. If the answered questions fulfill the reviewer's satisfaction, the questioner then can close the question and answer 


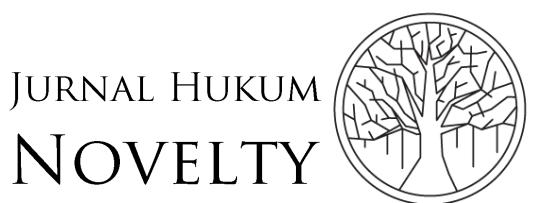

Volume 11, Issue 01, 2020, pp. 68-85

session and give an appreciation to the expert answers by giving them an appropriate rating. Furthermore, Community Admins can monitor their members' consulting activities.

The users of community members are granted access to use some of the main features in the Maduhukum app, such as Figure 13, which shows access to following the legal course so that they can learn the legal issues through the Maduhukum mobile application. Additionally, by viewing the legal counseling feature, as shown in Figure 14 , users will receive some other relevant information needed on the implementation of legal counseling in the community and given access to viewing the documents, as well as the counseling materials provided. Therewithal, by looking at the notification option, users can get information about further announcements from the community.

Figure 13. Extension Information

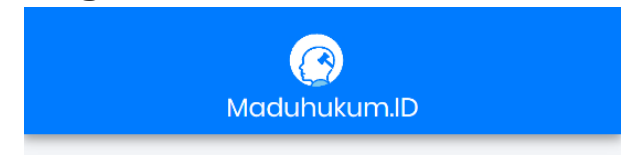

(i) Informasi Penyuluhan

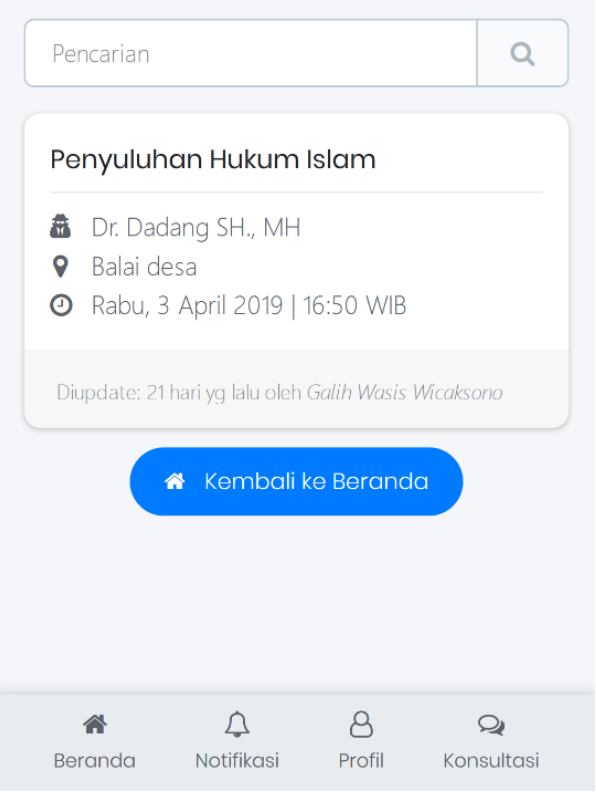

Figure 14. Legal Knowledge

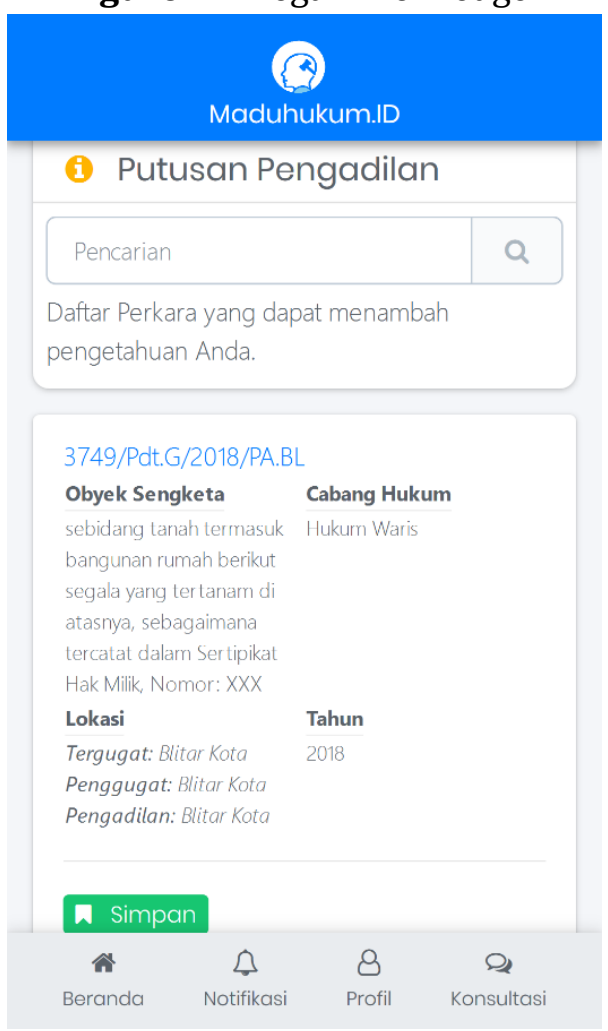

\section{Conclusion}

Issues faced in marital law can be concluded due to the causes such as the lack of husband's responsibility, husband and wife altercation, infidelity to the problem of child behavior caused by economic issues $(10 \%)$, the lack of education/knowledge (20\%), the lack of proper communication $(25 \%)$, and the society adverse influences (45\%). Meanwhile, the problems faced on inheritance matters are caused by disputes that happen between fellow heirs, the disagreement that occurs between adopted children and the main heirs caused by internal personal desire or self-interest to take control of the inheritance (40\%), as well as the lack of education/knowledge (60\%). 
It is a significant effort to give legal knowledge to society. Thus they could alter their attitude as shown in the above-provided data. By creating a knowledge management system, the law experts could gather side by side with information technology experts. By combining the legal experts' knowledge, the existing legislation, the judges' verdicts, and scientific articles with an informatic app, the society will understand and overcome the current faced-issues.

The combination then provided a current mobile app called Maduhukum, which extracted the legal knowledge from three sources: legislation, court decisions, and scientific research. The extraction results are stored into a database integrated with the information retrieval, so that information according to the knowledge is convenient to manage and use in the legal consultation process. The app also provided direct consultation between people to the expert, and then they could discuss and learn to overcome the legal issues within the community.

This research should be followed by another advanced study, which provided more and more collaboration of knowledge input. Thus, the current application could evolve to be a more critical tool of society to learn and practice their legal activities. Additionally, the impact of the Maduhukum app should be investigated further so that the app can support social-legal benefit to the community.

\section{References}

Afrianty, I., \& Marzuki, I. (2015). Prototipe penerapan knowledge management system pada sistem informasi kebudayaan Islam. Seminar Nasional Teknologi Informasi, Komunikasi Dan Industri (SNTIKI), 1(1r), 221-228. Retrieved from https://bit.ly/2Wn5xVI

Al-Fatih, S. (2018). Model pengujian peraturan perundang-undangan satu atap melalui Mahkamah KonstitusI. Jurnal Ilmiah Hukum LEGALITY, 25(2), 247. https://doi.org/10.22219/jihl.v25i2.6005

Al-Rizki, M. A., Wicaksono, G. W., \& Azhar, Y. (2017). The analysis of proximity between subjects based on primary contents using Cosine Similarity on lective. Kinetik, 2(4), 299. https://doi.org/10.22219/kinetik.v2i4.271

Boella, G., Caro, L. Di, Humphreys, L., Robaldo, L., Rossi, P., \& van der Torre, L. (2016). Eunomos, a legal document and knowledge management system for the Web to provide relevant, reliable, and up-to-date information on the law. Artificial Intelligence and Law, 24(3), 245-283. https://doi.org/10.1007/s10506-0169184-3

Diab, A. L. (2014). Peranan hukum sebagai social control, social engineering dan Social welfare. Jurnal Al-Adl, 7(2), 53-66. Retrieved from http://ejournal.iainkendari.ac.id/al-adl/article/view/219/209

Goodwin, L., \& Maru, V. (2017). What do we know about legal empowerment? Mapping the evidence. Hague Journal on the Rule of Law, 9(1), 157-194. https://doi.org/10.1007/s40803-016-0047-5

Hidayah, N. P., \& Komariah, K. (2019). Peningkatan kapasitas kelompok PKK Desa 
Sumbersekar Kecamatan Dau Kabupaten Malang untuk mengatasi problematika hukum waris Islam. Jurnal Penelitian Dan Pengabdian Kepada Masyarakat UNSIQ, 6(3), 122-127. https://doi.org/10.32699/ppkm.v6i3.719

Joko, B. S. (2010). Sistem informasi manajemen perguruan tinggi dalam bidang pendataan pendidikan tinggi. Jurnal Pendidikan dan Kebudayaan, 16(2), 146156. https://doi.org/10.24832/jpnk.v16i2.442

Krisnawaty, T., Nuraini, A., Andy Yentriyani, Dahlia Mahdani, Husein Muhammad, Kunthi Tridewiyanti, ... Rio Menajang, J. F. M. (2010). Pemenuhan hak-hak konstitusional warga negara (1st ed., Vol. 1). Jakarta: Komisi Nasional Anti Kekerasa Terhadap Perempuan.

Mardani. (2017). Hukum keluarga Islam di Indonesia (Vol. 1). Jakarta: Kencana. Retrieved from https://bit.ly/3dPK6mn

Marghobi, B. D. (2014). Tinjauan kriminologis faktor penyebab terjadinya tindak pidana pencurian kendaraan bermotor (Studi di Lembaga Pemasyarakatan Lowokwaru Malang). Jurnal Hukum, 21(April). Retrieved from http://hukum.studentjournal.ub.ac.id/index.php/hukum/article/view/538/52 8

Mawardi, D. R. (2015). Fungsi hukum dalam kehidupan masyarakat. Masalah Masalah Hukum, 44(3), 275-283. Retrieved from https://ejournal.undip.ac.id/index.php/mmh/article/view/12912/9706

Ngutra, T. (2016). Hukum dan sumber-sumber hukum. Supremasi, XI(2), 193-211. Retrieved from https://ojs.unm.ac.id/supremasi/article/view/2813/1514

Pengadilan Agama Kabupaten Malang. (2017). Perkara Pengadilan Agama Kab Malang 2016. Kepanjen. Retrieved from https://www.pamalangkab.go.id/frontend/img/laporanperkaraditerima2016.jpg

Pengadilan Agama Kota Malang. (2018). Laporan Perkara Diterima Pengadilan Agama Kota Malang. Kota Malang. Retrieved from http://www.pamalangkota.go.id/index.php/2018-11-11-14-58-01/2018-11-12-03-3830/2018-11-12-03-39-31/laporan-perkara-diterima

Pujadi, T., \& Tumar, T. (2016). Knowledge management di instansi pemerintah. Ethos Jurnal Penelitian Dan Pengabdian), 57-64. https://doi.org/10.29313/ETHOS.V0I0.1686.G1067

Purba, I. P. (2017). Penguatan budaya hukum masyarakat untuk menghasilkan kewarganegaraan transformatif. Jurnal Civics: Media Kajian Kewarganegaraan, 14(2), 146-153. Retrieved from https://journal.uny.ac.id/index.php/civics/article/view/16050

Soekanto, S. (2006). Pengantar penelitian hukum. Jakarta: UI Press.

Sonata, D. L. (2014). Metode penelitian hukum normatif dan empiris: Karakteristik khas dari metode meneliti hukum. Fiat Justisia Jurnal Ilmu Hukum, 8(1), 15-35. https://doi.org/10.25041/fiatjustisia.v8no1.283

Surianti, S., Banyal, N. A., \& Wahab, S. R. (2017). Knowledge management system penyakit sawit berbasis Android menggunakan pendekatan Usability $\begin{array}{llll}\text { Engineering. ILKOM Jurnal Ilmiah, } & \text { 9(3), }\end{array}$ 
https://doi.org/10.33096/ilkom.v9i3.189.361-367

Wiratraman, H. P. (2019). Tantangan metode penelitian interdisipliner dalam pendidikan hukum Indonesia. Mimbar Hukum, 31(3), 402-418. Retrieved from https://jurnal.ugm.ac.id/jmh/article/view/44305

Yunanto. (2019). Penegakan hukum spiritual terhadap pelanggaran dalam hukum keluarga. Jurnal Hukum Progresif, 7(1), 64-80. https://doi.org/10.14710/hp.7.1.i 